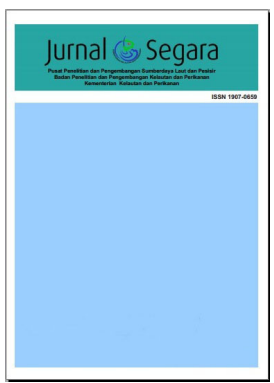

JURNAL SEGARA

http://pusriskel.litbang.kkp.go.id/segara

p-ISSN : 1907-0659

e-ISSN : 2461-1166

Accreditation Number: 766/AU3/P2MI-LIPI/10/2016

\title{
METABOLISME EMERGI SUMBERDAYA KOTA PESISIR DAN APLIKASINYA UNTUK EVALUASI PERENCANAAN KOTA PESISIR YANG BERKELANJUTAN, STUDI KASUS KOTA MAKASSAR
}

\section{(EMERGY METABOLISM OF THE COASTAL CITY AND ITS APLICATION TO EVALUATE THE SUSTAINABLE URBAN PLANNING, CASE IN MAKASAR CITY)}

\author{
Syahrial Nur Amri'), Luky Adrianto ${ }^{2)}$, Dietriech G Bengen ${ }^{3)}$, \& Rahmat Kurnia ${ }^{2)}$ \\ 1) Pusat Penelitian dan Pengembangan Sumberdaya Laut dan Pesisir, Balitbang KP-KKP \\ 2)Program Studi Pengelolaan Sumber Daya Laut \& Pesisir-IPB Bogor \\ 3) Program Studi IImu Kelautan-IPB Bogor \\ Diterima: 27 September 2016; Diterima setelah perbaikan: 25 Maret 2017 ; Disetujui terbit:27 Maret 2017
}

\begin{abstract}
ABSTRAK
Kestabilan dan keberlanjutan suatu sistem sosial ekologi di Kota Pesisir tergantung pada optimal dan efisiennya pemanfaatan energi sumber daya yang tersedia. Siklus autokatalitik dalam metabolisme kota pesisir memberikan gambaran nyata bagaimana energi sumber daya mengalir antara manusia dan sumber daya alam dan bagaimana manusia mengatur dan memanfaatkan energi sumber daya alam yang tersedia. Penelitian ini bertujuan untuk memodelkan siklus energi dan meterial dalam batas sistem kota pesisir yang mengakomodir semua sumber daya alam yang menghasilkan energi yang dimiliki Kota Makassar dalam rentang waktu tertentu, sehingga mampu menunjukkan tren pemanfaatan dan keberlanjutan sistem dalam upaya menstabilkan diri terhadap dinamika penggunaan lahan dan pertumbuhan penduduk. Metode penelitian yang digunakan didasarkan pada konsep perhitungan aliran emergi dan indeks penilaian keberlanjutan metabolisme kota pesisir. Hasil penelitian menunjukkan bahwa total emergi yang mengalir pada 2001 sebesar 1,68E+21 Sej, meningkat menjadi 2,02E+21 Sej pada 2015. Hasil analisis indeks keberlanjutan menunjukkan bahwa energi sumber daya lokal sudah tidak mampu memenuhi kebutuhan energy masyarakat Kota Makassar, dan untuk memenuhi ketercukupan energi dalam sistem, input energi berupa impor sumber daya mendominasi aliran energi dalam sistem. Tentunya diperlukan efisiensi dalam pemanfaatan energi sumber daya, agar keberlanjutan metabolisme kota pesisir dapat terus berlangsung.
\end{abstract}

Kata kunci: Metabolisme perkotaan, analisis aliran emergi, keberlanjutan kota pesisir.

\section{ABSTRACT}

The stability and sustainability of socio-ecological system in the Coastal Cities depend on the optimal and efficient of the utilization of energy resources available. Autocatalytic cycles of the coastal urban metabolism gives a real picture of how energy flows between human resources and natural resources and how people organize and utilize the natural resources of energy available. The aims of this study are modelling the energy and material cycles of Makassar City during certain periods and showing the trend of utilization and sustainability of the system in an effort to stabilize themselves to the dynamics of the land use and population growth. The method used the concept of emergy flow and sustainability indice of coastal urban metabolism. The results showed that the emergy total flowing in 2001 was $1.68 E+21$ Sej, increasing to $2.02 E+21$ Sej by 2015. The sustainable indices analysis shows that the local energy resources can not suffice the needs and consumption patterns of Makassar community, and to suffice the energy adequacy in the system, the energy input was dominated by energy import. It needed efficiency of the utilization of energy resources, so that the coastal urban metabolism can sustainable.

Keywords: urban metabolism, emergy flow analysis, sustainability of coastal city.

Corresponding author:

Jl. Pasir Putih I Ancol Timur, Jakarta Utara 14430. Email: sn_amri@gmail.co.id 


\section{PENDAHULUAN}

Kota pesisir merupakan suatu sistem tata ruang kota yang secara geografis terletak di wilayah pesisir dimana penduduk, ekonomi, ilmu pengetahuan, teknologi, budaya, sumber daya, dan lingkungan saling terintegrasi. Nilai strategis kota pesisir baik dari aspek geografi maupun kekayaan sumber daya menjadi daya tarik bagi manusia untuk berbondongbondong memanfaatkan dan mengelola wilayah tersebut. Kondisi tersebut tentu saja mengakibatkan semakin besarnya tekanan dan penurunan kemampuan daya pulih lingkungan tersebut. Peningkatan jumlah penduduk akan meningkatkan pula kebutuhan lahan terbangun, yang tentu saja akan merubah struktur dan fungsi lahan itu sendiri. Peningkatan jumlah penduduk juga menyebabkan peningkatan jumlah konsumsi, perubahan pola hidup, upaya eksploitasi sumber daya yang lebih besar, serta peningkatan jumlah emisi limbah. Kota pesisir juga merupakan sebuah sistem organisme yang kompleks dengan berbagai proses metabolisme energi di dalamnya. Tanah dan air dimanfaatkan dan diubah menjadi modal materi dengan serangkaian kegiatan sosial ekonomi perkotaan dalam jangka waktu tertentu, yang kemudian sisanya akan dikonversi untuk limbah dan dilepaskan ke lingkungan.

Sebagai suatu sistem, kota pesisir yang merupakan suatu sistem organisasi yang kompleks dan semi terbuka, pada saat yang sama, harus bertukar materi dan energi yang diperlukan untuk mempertahankan operasi mereka, dan mengeluarkan limbah yang mereka hasilkan dengan lingkungan luar (Kimberley, 2001), dan terus menjalankan fungsi dan proses metabolisme yang dibutuhkan untuk menstabilkan diri, beradaptasi dengan bentuk perubahan dan dinamika penggunaan lahan, serta perkembangannya (Wang, 2015). Kota pesisir juga merupakan sistem organisme yang kompleks, dimana fungsi dan proses metabolisme yang berlangsung dibutuhkan untuk menstabilkan diri, beradaptasi dengan bentuk perubahan dan dinamika penggunaan lahannya. Proses penstabilan diri dan adaptasi di kota pesisir dapat dilakukan melalui usaha ekploitasi sumber daya lokal maupun energi yang diperoleh dari luar sistem, juga melalui penerapan kebijakan ketahanan energi, dimana kebijakan tersebut difokuskan di wilayah perkotaan Indonesia, yang merupakan konsumen dari energi sumber daya tersebut.

Keberlanjutan sebuah kota dapat tercermin secara spasial dari pola pemanfaatan ruang kota-kota di Indonesia, pada umumnya dapat dikatakan tidak mendukung terwujudnya kota yang berkelanjutan, karena pemanfaatan ruang untuk kawasan terbangun cenderung ekspansif dan meyebar (sprawling), serta mengkonversi ruang-ruang alami yang memiliki fungsifungsi ekologis seperti darah resapan air, hutan, situ, DAS, ekosistem pantai, dan lahan alami lainnya (Mukaryanti et al., 2006). Sebagaimana kota-kota besar di Indonesia, Kota Makassar yang terletak di pesisir, memiliki nilai strategis dan sumber daya yang sangat besar. Keberadaan lahan kosong yang sebagian besar merupakan lahan dengan fungsi budidaya perikanan, pertanian, dan vegetasi, semakin berkurang seiring dengan semakin pesatnya pembangunan fisik yang berlangsung. Peningkatan jumlah penduduk yang mengkonversi lahan-lahan terbuka dan buangan limbah domestik dan industri juga menambah besarnya tekanan dan degradasi terhadap lingkungan dan ekosistem yang ada. Peningkatan jumlah lahan terbangun akan merubah struktur dan fungsi lahan itu sendiri, sedangkan peningkatan jumlah penduduk akan menyebabkan terjadinya peningkatan jumlah konsumsi dan perubahan pola hidup, serta upaya eksploitasi sumber daya yang lebih besar serta peningkatan jumlah emisi limbah.

Model metabolisme emergi sumber daya kota pesisir memberikan gambaran sederhana mengenai pemanfaatan, dimana sumber daya penghasil energi dimanfaatkan dalam aktifitas manusia merupakan simulasi sederhana dari kompleksitas arus materi dan energi yang mengalir dalam kawasan kota pesisir sebagai sebuah sistem sosial ekologi (social ecological system). Dengan menggunakan simulasi, maka model akan mengkomputasikan kompleksitas dari metabolisme energi pada wilayah kota pesisir menjadi lebih sederhana sehingga memudahkan dalam interpretasi dan analisis. Analisis yang digunakan dalam menggambarkan aliran energi dan materi didasarkan pada indikator emergi sumber daya dan penggunaan lahan perkotaan. Model yang dihasilkan akan menggambarkan karakter dan siklus pemanfaatan energi dari sumber daya (useful energy) pesisir dan upayanya dalam menstabilkan diri dalam siklus metabolisme sosial.

Berbagai permasalahan sumber daya energi yang terjadi di Kota Pesisir menjadi penting untuk dikaji, sebab identifikasi masalah yang tepat dan komprehensif akan menghasilkan bentuk pengelolaan dan pemanfaatan energi yang baik, yang akan menjamin terciptanya keseimbangan dan kelestarian fungsi sumber daya itu sendiri. Hal lainnya adalah bagaimana memecahkan masalah kebijakan lingkungan yang relatif sulit untuk dipecahkan, karena solusinya tergantung pada keakuratan dalam menyeimbangkan kebutuhan antara human systems dan nature, serta belum adanya cara yang baik untuk mengekspresikan dampak sosial ekonomi dan dampak lingkungan secara bersama-sama (Jatiningrum, 2012). Sebagai contoh, bahwa selama ini, laporan keuangan sektor 
publik yang ada di Indonesia, tidak pernah mencantumkan sumber daya alam sebagai sumber energi. Neraca yang dihasilkan oleh pemerintah hanya berkutat pada aset yang dimiliki dan dikelola oleh negara dan tidak pernah berbicara mengenai sumber daya alam dan energi yang dikuasai oleh negara/ pemerintah. Padahal sumber daya alam merupakan kekayaan yang patut diperhitungkan dan neraca yang memasukkan sumber daya alam sebagai sumber energi, bisa digunakan sebagai dasar pengambilan keputusan.

Dalam konsep metabolisme Perkotaan (Urban Metabolism), masyarakat melalui aktifitasnya, menggerakkan dan mengelola proses aliran material dan energi dalam lingkungan alam mereka. Mereka mengambil sumber daya alam dan menggunakannya untuk makanan, mesin, bangunan, infrastruktur, pemanasan dan banyak produk lainnya dan akhirnya mengembalikan mereka dalam bentuk limbah dan emisi ke lingkungan mereka kembali (Haberl et al., 2001). Aplikasi dari konsep metabolisme biologi ke sistem sosial tergantung pada keberlanjutan material dan energi dalam rangka pemeliharaaan struktur internalnya. Sedangkan Haberl et al. (2001) memandang metabolisme sosial sebagai sistem ekonomi yang berkaitan dengan aliran material dan energi yang diubah dalam bentuk nilai barang dan jasa yang dikonsumsi manusia, menghasilkan limbah, panas dan emisi lain yang dibuang ke lingkungan. Dampaknya terhadap lingkungan dapat diukur besarannya melalui kebutuhan sejumlah material dari dan kembali ke lingkungannya (Eurostat, 1999).

Kota pesisir sebagai suatu wilayah yang memiliki nilai strategis tinggi, menjadikannya rentan terhadap perubahan penggunaan lahan. Lahan kosong yang dikonversi menjadi lahan terbangun, sebagian besar merupakan lahan produktif, baik sebagai lahan budidaya tambak, sawah pertanian, kebun dan ladang, serta lahan dengan fungsi ekologi seperti hutan dan rawa. Perubahan penggunaan lahan juga akan menggambarkan dinamika pemanfaatan energi sumber daya baik lokal maupun tambahan input energi dari luar. Sebagai suatu sistem yang kompleks, pemanfaatan energi sumber daya kota pesisir akan tergambar sebagai suatu siklus atau metabolisme sosial ekologi, dimana masyarakat dan pemerintah menjadi aktor utama dalam siklus metabolisme dan sumber daya alam menjadi objeknya.

Metabolisme emergi kota pesisir merupakan konsep yang diadopsi dari konsep metabolisme sosial (social metabolism). Haberl et al. (2001) memandang metabolisme sosial sebagai sistem ekonomi yang berkaitan dengan aliran material dan energi yang diubah dalam bentuk nilai barang dan jasa yang dikonsumsi manusia, menghasilkan limbah, panas dan emisi lain yang dibuang ke lingkungan (Gambar 1).

Sedangkan menurut Giampietro \& Kozo. (2000), manusia mengubah lingkungan dimana mereka hidup dalam rangka meningkatkan efektivitas proses produksi dan konsumsi barang dan jasa dalam

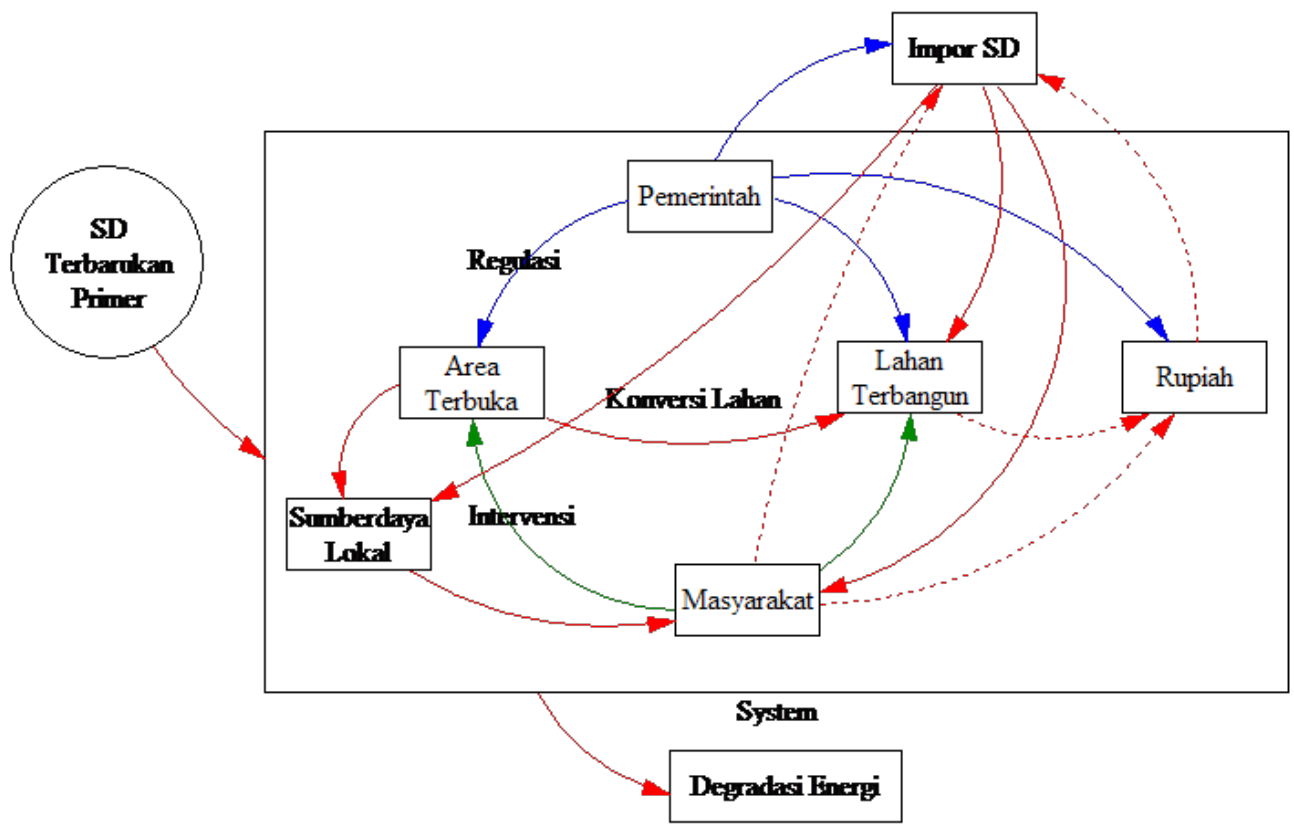

Gambar 1. Ilustrasi Sebuah Sistem Metabolisme Emergi Sumber daya Lahan Perkotaan. 
masyarakat mereka. Dalam hal biofisik, proses selforganisasi masyarakat manusia dapat dilihat sebagai kemampuan untuk menstabilkan jaringan arus materi dan energi yang mewakili apa yang diproduksi dan apa yang dikonsumsi dalam proses ekonomi. Agar berkelanjutan, proses tersebut harus: (1) sesuai dengan aspirasi masyarakat, (2) kompatibel dengan stabilitas ekosistem alam dan manusia, (3) kompatibel dengan stabilitas sosial dan lembaga-lembaga dan proses politik, (4) layak secara teknis, dan (5) ekonomis.

Konsep metabolisme perkotaan pertama kali diperkenalkan oleh Wolman pada 1965, yang menjadi dasar untuk mengembangkan kota dan hubungan masyarakat dan sumber daya yang berkelanjutan. Metabolisme perkotaan sendiri dapat didefinisikan sebagai jumlah total proses teknis dan sosial ekonomi yang terjadi di kota-kota, menghasilkan pertumbuhan, produksi energi, dan penghapusan limbah (Kennedy et al., 2007). Metabolisme perkotaan adalah titik fokus ekologi perkotaan dimana analisis yang terlibat dalam proses di antaranya pertukaran bahan dan konversi energi, serta penggunaan dan pembuangan mereka (Qing et al., 2015). Penelitian mengenai metabolisme perkotaan (urban metabolism) mengintegrasikan teoriteori yang multidisiplin, meliputi perspektif geografi fisik, biologi, ekologi, ekonomi, dan sosiologi.

Salah satu konsep perhitungan metabolisme sosial yang bisa diterapkan untuk mengevaluasi bentuk pemanfaatan energi di kota pesisir adalah konsep emergy accounting. Emergi, yaitu energi yang telah digunakan baik secara langsung atau tidak langsung untuk menghasilkan suatu produk atau jasa, yang diukur dengan satuan emjoule. (Odum, 1986). Dari tahun 1975 hingga saat ini, konsep emergi dan metodologi berkembang secara signifikan. Istilah "emergy" diciptakan oleh David Scienceman pada 1983 dengan menggabungkan kata-kata dalam "embodied energy/energi diwujudkan," Odum kemudian menggunakan untuk merujuk energi matahari total yang dibutuhkan untuk membuat sebuah produk atau menyediakan layanan (Brown \& Ulgiati, 2004).

Kota Makassar pada awal mulanya terbentuk sebagai kota, merupakan wilayah yang ramai oleh aktifitas masyarakat pesisir, baik sebagai nelayan, petambak, petani, dan pedagang. Masyarakat Kota Makassar banyak memenuhi kebutuhan hidupnya dengan memanfaatkan sumber daya alam lokal. Seiring waktu berlalu, perputaran ekonomi yang cepat memunculkan ketertarikan orang dari luar untuk datang dan mencari nafkah. Pertumbuhan jumlah penduduk berarti kebutuhan akan lahan terbangun juga semakin meningkat. Konversi lahan terbangun menurunkan luasan area terbuka yang notabene area terbuka sebagian berfungsi sebagai lahan tambak, persawahan, dan kebun, atau dengan kata lain, produksi sumber daya pangan semakin menurun akibat menurunnya luas area produksi dan meningkatnya kebutuhan dan konsumsi akibat peningkatan jumlah penduduk. Upaya pemenuhan kebutuhan energi sumber daya dilakukan untuk menstabilisasi aliran atau proses produksi dalam sistem, atau dengan kata lain, masyarakat berusaha untuk menstabilkan dan meningkatkan struktur dan fungsi masyarakat mereka sesuai dengan satu set internal "nilai-nilai" dan "tujuan" atau dalam hal biofisik, proses self-organisasi masyarakat dapat dilihat sebagai kemampuan untuk menstabilkan jaringan arus materi dan energi yang mewakili apa yang diproduksi dan apa yang dikonsumsi dalam proses ekonomi (Giampietro \& Kozo, 2000).

Penelitian ini bertujuan untuk memodelkan siklus energi dan material dalam batas sistem kota pesisir Makassar yang mengakomodir semua sumber daya alam yang menghasilkan energi yang dimiliki Kota Makassar dalam rentang waktu tertentu, sehingga mampu menunjukkan tren pemanfaatan dan keberlanjutan sistem dalam upaya menstabilkan diri terhadap dinamika penggunaan lahan dan pertumbuhan penduduk. Pada gilirannya model ini dapat menjadi dasar kebijakan dalam pemanfaatan sumber daya alam serta dampaknya terhadap lingkungan kota pesisir dan atau sistem secara keseluruhan. Dengan mengevaluasi sistem yang kompleks menggunakan basis emergi, input utama dari ekonomi dan lingkungan dapat terintegrasi secara bersama-sama untuk menganalisis pertanyaan kebijakan publik dan pengelolaan terkait sumber daya alam yang menghasilkan energi serta lingkungan yang ada di dalamnya.

\section{METODE PENELITIAN}

\section{Tahapan penelitian}

Secara umum, model siklus energi sumber daya kota pesisir dilakukan melalui beberapa tahapan (Voora \& Charles, 2010), antara lain, mendefenisikan dan menetapkan batasan sistem, membangun diagram sistem untuk menggambarkan fitur sistem (leftright energy systems), input dan output untuk dianalisis, menyusun tabel emergi yang merangkum nilai-nilai emergy dan aliran dan stok sistem, mengkonversi stok dan aliran emergi dari unit energi atau massa untuk unit setara emergi dengan menggunakan koefisien transformasi dan menganalisis status keberlanjutan metabolisme sosial Kota Pesisir dengan menggunakan sejumlah indikator emergi. Tahapan penyusunan diagram sistem dibangun berdasarkan acuan Odum (1996). 


\section{Teknik Pengumpulan Data}

Data yang digunakan dalam penelitian ini melingkupi seluruh objek-objek sumber daya alam Kota Makassar yang dapat diperbaharui, tidak dapat diperbaharui, serta sumber daya alam yang diimpor dari luar untuk memenuhi kebutuhan energi di Kota Makassar. Objek sumber daya alam yang dapat diperbaharui di antaranya, sinar matahari, angin, hujan, kelembaban dan tekanan udara, pertanian, perikanan, perkebunan, peternakan, dan kehutanan. Objek sumber daya alam yang tidak dapat diperbaharui seperti sumber daya barang tambang. Sedangkan sumber daya yang diimpor di antaranya, bahan bakar untuk industri, perumahan, dan transportasi, listrik, barang dan jasa, makanan dan minuman. Data yang diambil berupa informasi terkait jumlah hasil produksi pada masing-masing objek dan besaran konsumsi masyarakat pada rentang tahun 2001, 2008, dan 2015. Sedangkan sumber data yang digunakan dalam penelitian ini merupakan data yang diperoleh dari beberapa sumber, diantaranya data BPS Kota Makassar, PLN Regional Makassar, Pertamina Region VII Makassar, Bappeda Kota Makassar, Dinas Kehutanan Kota Makassar, Dinas Perindustrian Kota Makassar, dan Dinas Kelautan dan Perikanan Kota Makassar.

\section{Analisis Data}

\section{Perhitungan Emergi (Emergy Accounting)}

Menurut Odum. (1996), emergi didefinisikan sebagai total energi dari satu bentuk yang digunakan secara langsung dan tidak langsung untuk membuat bentuk yang lain dari energi, atau untuk menghasilkan sebuah produk atau menyediakan suatu jasa (Voora \& Thrift, 2010). Emergi menggunakan dasar thermodinamika dari semua bentuk energi, sumber daya, dan jasa manusia, dan mengubahnya menjadi setara dari satu bentuk energi. Satuan emergi adalah solar emjoule (Sej), unit yang merujuk pada energi yang tersedia (energy available) dari satu jenis yang dikonsumsi dalam tansformasi (Brown \& Ulgiati, 1998). Odum (1996) juga mendefenisikan analisis emergi sebagai metode untuk mengukur nilai atau kuantitas materi atau energi (dengan evaluasi kriteria-surya emergi metrik tujuan dan seragam) yang digunakan untuk mengubah input alam atau manusia yang berbeda yang mengalir dari material, energi, informasi, dan modal. Ini dibuat relatif terhadap standar pengukuran seragam, dengan menggunakan faktor konversi spesifik dan dengan menggabungkan sosial ekonomi dengan sistem eco-lingkungan, untuk menganalisis arus dan transformasi bahan dan energi secara kuantitatif. Pendekatan emergi menggunakan sistem penilaian alam, yang didasarkan pada arus energi yang tersedia yang disesuaikan dan diubah menjadi bentuk yang memiliki kapasitas untuk melakukan pekerjaan yang lebih banyak (Voora \& Charles, 2010). Pendekatan emergi yang komprehensif dan obyektif dalam menilai aliran barang dan jasa dalam suatu sistem kota pesisir, diungkapkan dalam unit Solar emergy joule (Sej atau emjoules). Adapun persamaan yang digunakan, sebagai berikut :

Emergy $($ sej $)=$ Avalaible Energy $(\mathrm{J}) \mathrm{x}$ Transformity $(\mathrm{sej} / \mathrm{J})$........ 1) Dimana: Sej : Solar emergy joule, J: Joule

Karena semua barang dan jasa yang berasal dari lingkungan, masyarakat dan ekonomi dapat dinyatakan dalam satuan emergi, keragaman tersebut dapat langsung dibandingkan untuk menilai kondisi dan keberlanjutan sistem. Pendekatan energi memberikan kebijakan dan pengambilan keputusan melalui sistem penilaian sehingga manusia dan lingkungan alam dapat dikelola dengan lebih baik (Voora \& Thrift, 2010).

Aliran emergi metabolisme kota pesisir Makassar tergambarkan melalui perhitungan data bahan, energi, dan arus modal selama interval tujuh tahun (2001, 2003, 2006, 2008, 2011, 2013 dan 2015). Perhitungan tersebut meliputi perhitungan emergi dari sumber daya terbarukan, sumber daya tak terbarukan, impor sumber daya dari luar, jasa, dan limbah. Nilai energi surya dari setiap item ditunjukkan dalam Tabel 3. Data mentah yang digunakan dalam perhitungan emergi bersumber dari data statistik BPS Kota Makassar, BPS Propinsi Sulsel, dan Statistik Perikanan Propinsi Sulsel. Sedangkan data penggunaan lahan diperoleh melalui hasil olah data citra satelit.

Data sumber daya alam yang terdapat di Kota Makassar secara multi-series yang dikumpulkan tersebut kemudian dikelaskan ke dalam kelas sumber daya terbarukan, sumber daya non-terbarukan, dan sumber daya yang diimpor. Materi dan energi yang digunakan secara langsung oleh masyarakat dimana arus materi dan energi yang digunakan pada tingkat yang lebih lambat dari tingkat regenerasi mereka, seperti produksi tanaman bahan makanan, produksi tanaman sayur-sayuran, produksi tanaman buahbuahan, produksi tanaman perkebunan, produksi hasil peternakan, dan produksi hasil perikanan diperlakukan sebagai sumber daya yang terbarukan (R). Materi dan energi non terbarukan yang digunakan masyarakat (konsumen) yang mengalir berasal dari penyimpanan yang digunakan pada tingkat lebih cepat daripada tingkat regenerasi mereka, seperti: air yang dikonsumsi diasumsikan menjadi non-terbarukan, karena resiko dari over eksploitasi sebagai akibat tingkat populasi penduduk yang terus bertambah, tanah/lahan (N). Bahan bakar yang dibeli, listrik, barang (goods), dan tenaga kerja, diperlakukan sebagai sumber daya yang diimpor $(F)$. 
Perhitungan emergi kemudian dilakukan melalui tahapan konversi satuan sumber daya yang telah dikelaskan tersebut ke dalam satuan joule. Proses perhitungan dimulai dengan mengubah setiap satuan rincian data mentah pada setiap item yang berbeda menjadi jumlah energi (joule). Khusus untuk jumlah produksi tanaman bahan makanan, produksi tanaman sayur-sayuran, produksi tanaman buah-buahan, produksi tanaman perkebunan, produksi hasil hutan, produksi hasil peternakan dan perikanan untuk dapat diubah menjadi energi (joule) terlebih dahulu mesti melewati pengubahan kalori.

Nilai transformity diperlukan untuk menyamakan semua hasil perhitungan (jenis input energi) ke dalam satuan setara energi surya sehingga memungkinkan untuk dilakukan perbandingan. Produk akhir dari tahap ini adalah tabel arus emergi. Nilai tranformiti (Sej/J) yang diadopsi dalam melakukan analisis adalah bersumber dari Qing. (2015) dan Voora \& Thrift. (2010). Selanjutnya dilakukan perhitungan indeks emergi sumber daya yang diklasifikasikan ke dalam sumber daya terbarukan $(R)$, sumber daya tidak terbarukan $(\mathrm{N})$, dan sumber daya yang diimpor $(\mathrm{F})$.

\section{Nilai Emergi Berdasarkan Sistem Evaluasi Metabolime Perkotaan}

Untuk mengevaluasi status metabolisme perkotaan digunakan lima indeks yaitu, fluks, struktur, intensitas, efisiensi, dan rasio emisi limbah, sebagaimana ditunjukkan dalam Tabel 1.

\section{Status Keberlanjutan Metabolisme Emergi Berdasarkan Evaluasi Penggunaan Lahan di Kota Pesisir}

Lahan terbangun adalah suatu sistem konsumsi, yang mengkonsumsi banyak sumber daya lokal dan input material, termasuk bahan baku, bahan bakar fosil, makanan, barang, dan jasa; dan ekspor barang dan jasa ke luar juga. Lahan pertanian adalah sistem produktif yang input dari bahan organik dan bahan pembantu industri memungkinkan produksi komoditas pertanian melalui fotosintesis dan reaksi kimia lainnya, dimana produk ini kemudian diekspor ke area bangunan dan lingkungan luar (Qing et al., 2015).

Aliran emergi yang besar di wilayah perkotaan sebanding dengan peningkatan pemanfaatan lahannya.

Tabel 1.

Indeks Emergi untuk Mengevaluasi Metabolisme Sosial Kota Pesisir

\begin{tabular}{llll}
\hline No & Indeks & Sub-Kelas & Formula \\
\hline 1 & Flux (U) & - & $\mathrm{R}+\mathrm{N}+\mathrm{F}$ \\
& & $\mathrm{St1}$ & $\mathrm{R} /(\mathrm{R}+\mathrm{N})$ \\
2 & Structures (St) & $\mathrm{St2}$ & $\mathrm{N} / \mathrm{U}$ \\
& & $\mathrm{St3}$ & $\mathrm{F} / \mathrm{U}$ \\
3 & Intensity (I) & - & U/Population \\
4 & EmRp & - & $\mathrm{U} / \mathrm{GDP}$ \\
5 & Waste Emission Ratio (W) & - & Ew/U \\
\hline Sumber: Odum (1996) & &
\end{tabular}

Dimana :

$\mathrm{U} \quad=$

St $\quad=$

St1 $=$

St2 =

St3 =

$1=$

$\operatorname{EmRp} \quad=$

Jumlah bahan dan energi dari sistem internal dan lingkungan eksternal, yang merupakan jumlah dari masukan energi. Struktur atau Komposisi bahan metabolisme dan energi. Dalam penelitian ini S dibagi dalam 3 sub kelas, yaitu: Persentase sumber daya terbarukan $(R)$ yang menjelaskan nilai dari sumber daya terbarukan yang dikonsumsi dalam proses pembangunan perkotaan.

Persentase yang menyumbang energi sumber daya tak terbarukan untuk dan dari total masukan emergi.

Persentase yang menyumbang sumberdaya impor bagi total input emergi $(U)$, dan digunakan untuk mengekspresikan tingkat ketergantungan pembangunan perkotaan pada sumber daya eksternal.

Intensitas atau pemanfaatan emergi per kapita adalah rasio dari total emergi dengan jumlah populasi. Indeks ini menunjukkan bagaimana konsumsi terkait populasi atau gambaran mengenai tanggung jawab setiap penduduk dalam penggunaan sumberdaya, atau digunakan untuk mengevaluasi standar hidup masyarakat, pola konsumsi dan tanggung jawab masyarakat terhadap pemanfaatan sumberdaya.

rata-rata jumlah emergy yang dibeli dengan menghabiskan satu rupiah (sej/rupiah). EmRp menginformasikan daya beli rupiah dalam hal kekayaan ril (emergy) yang bisa dibeli. Sebuah nilai emergy yang rendah terhadap rupiah tidak berarti bahwa emergy kurang dalam sirkulasi, karena pada kenyataannya, banyak daerah dengan rasio emergy untuk rupiah yang rendah memiliki nilai penggunaan emergy perkapita yang sangat tinggi. Ini hanya berarti bahwa wilayah ini lebih tergantung pada penggunaan sumberdaya lingkungan dari luar batas-batas wilayah mereka, dan berakibat pada penggunaan uang untuk memperleh barang dan jasa untuk mendukung perekonomian.

$\mathrm{W} \quad=\quad$ Rasio emisi limbah adalah persentase limbah, atau hitungan emisi emergi dari fluks (U). Input Emergy Sumberdaya Terbarukan Lokal

Input Emergy Sumberdaya Tak Terbarukan Lokal

Total Emergy Input (Purchase) atau Input Pembelian Emergy dari Luar Sistem (Import) 
Tabel 2.

Indeks Emergi untuk Mengevaluasi Metabolisme Penggunaan Lahan

\begin{tabular}{lll}
\hline No & Indeks & Persamaan \\
\hline 1 & Empower Density (ED) & U/Land Area \\
2 & Emergy Yield Ratio & (EYR) U/F \\
3 & Environmental Load Ratio (ELR) & $(\mathrm{N}+\mathrm{F}) / \mathrm{R}$ \\
4 & Emergy Sustainable Indices (ESI) & $\mathrm{EYR/ELR}$ \\
5 & Emergy Investment Ratio (EIR) & $\mathrm{F} /(\mathrm{N}+\mathrm{R})$ \\
\hline Sumber: Odum. (1996). &
\end{tabular}

\begin{tabular}{|c|c|c|}
\hline \multicolumn{3}{|c|}{ Keterangan: } \\
\hline ED & $=$ & $\begin{array}{l}\text { Empower Density adalah emergi yang dikonsumsi per unit lahan; nilai yang lebih tinggi menunjukkan ekonomi lebih } \\
\text { sejahtera, sedangkan lahan mendapatkan tekanan yang lebih. }\end{array}$ \\
\hline EYR & $=$ & Emergy Yield Ratio merupakan rasio dari total output emergi dan total input emergi \\
\hline LR & $=$ & $\begin{array}{l}\text { Environment Loading Ratio adalah rasio emergi sumber daya tak terbarukan dan emergi sumber daya yang diimpor } \\
\text { dalam bentuk barang dan jasa ke sumberdaya terbarukan, yang digunakan untuk menunjukkan tekanan beban lahan } \\
\text { pada ekosistem lokal. nilai-nilai yang lebih tinggi menunjukkan bahwa beban lingkungan lahan yang lebih tinggi }\end{array}$ \\
\hline & $=$ & $\begin{array}{l}\text { Emergy Sustainable Indice adalah rasio perbandingan hasil panen emergi untuk rasio beban lingkungan lahan } \\
\text { (misalnya, rasio hasil emergi per unit tekanan beban lahan); nilai yang lebih tinggi menunjukkan lebih banyak manfaat } \\
\text { sosial ekonomi per unit tekanan beban lahan dan pemanfaatan lahan yang lebih berkelanjutan. }\end{array}$ \\
\hline $\mathrm{R}$ & $=$ & $\begin{array}{l}\text { Emergy Investment Ratio adalah rasio emergi yang dibeli dari luar sistem ke emergy yang dipasok oleh sumber energi } \\
\text { terbarukan dan tidak terbarukan dari dalam sistem. EIR menunjukkan proporsi investasi terhadap sumber daya } \\
\text { ekonomi asli daerah dan mencerminkan intensitas pembangunan. }\end{array}$ \\
\hline
\end{tabular}

Besarnya konversi lahan tidak terbangun menjadi lahan terbangun dan bentuk kebijakan pengelolaannya menjadi salah satu indikator dan tolak ukur keberlanjutan sistem kota tersebut. Selain meningkatnya penggunaan lahan akibat peningkatan laju ekonomi kota pesisir menyebabkan pula meningkatnya tekanan terhadap ekosistem pesisir. Baik akibat degradasi lahan maupun akibat tekanan buangan limbah. Untuk mengevaluasi status keberlanjutan metabolik dari lahan tidak terbangun, lahan terbangun, dan penggunaan lahan lain dari kawasan kota pesisir secara keseluruhan, khususnya Kota Makassar digunakan empat indeks (Tabel 2), dan dilakukan analisis perubahan nilai-nilai mereka dari waktu ke waktu.

\section{HASIL DAN PEMBAHASAN}

\section{Batas Sistem}

Model metabolisme emergi penggunaan lahan di Kota Pesisir dibangun pada suatu sistem dinamis yang tertutup, namun bukan berarti bahwa wilayah perkotaan diisolasi. Manusia datang dan pergi dari sistem dan terjadi interaksi berupa perdagangan. Lingkaran atau siklus sebab dan akibat bisa mencapai luar dari batas sistem dan kembali. Wilayah kota pesisir digambarkan sebagai sebuah sistem kehidupan, dimana sistem kontrol sendiri yang mengatur pergerakan penduduknya ke dan dari lingkungan luar. Yang menjadi perhatian utama adalah bagaimana wilayah kota pesisir berperan relatif terhadap lingkungan luarnya. Jika wilayah tersebut lebih menarik bagi sekelompok orang, terjadilah migrasi masuk. Jika wilayah tersebut kurang

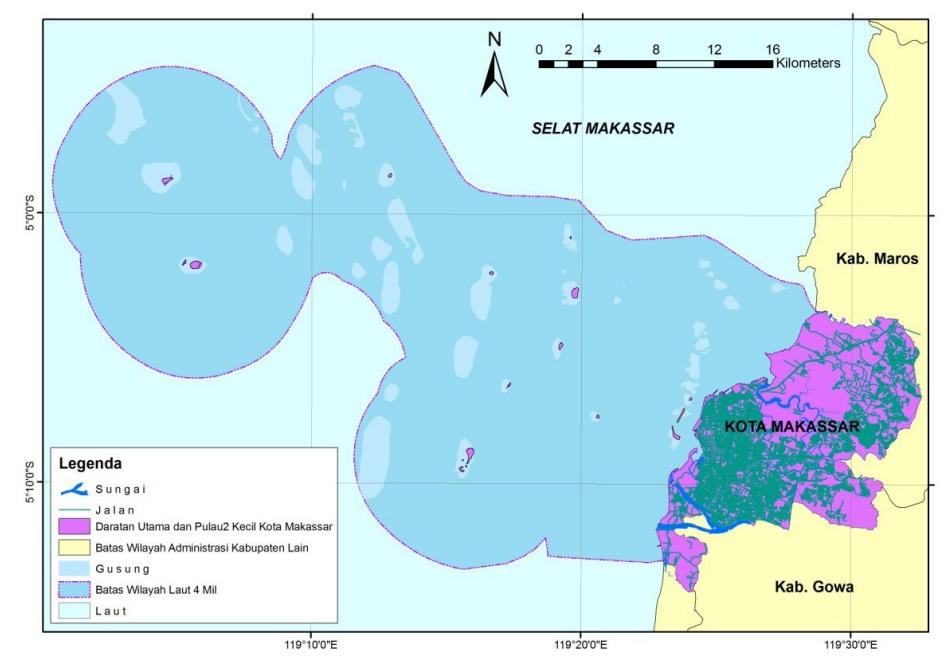

Gambar 2. Lokasi Penelitian sebagai Batas Sistem Penelitian. 
menarik, maka terjadilah migrasi keluar.

Agar batas penelitian/sistem terdefenisi dengan jelas, maka dalam penelitian ini, sistem dibatasi berdasarkan batas administratif yaitu Kota Makassar. Sebagai Kota Pesisir, Kota Makassar berbatasan langsung dengan Selat Makassar dan kawasan Kepulauan Spermonde, sehingga secara ekologi, Kota Makassar sangat dipengaruhi dan tergantung akan keberadaan sumber daya laut dan pesisir (Gambar 2). Karena berbatasan dengan laut, masyarakat Kota Makassar sebagian besar menggantungkan kondisi ekonominya dengan laut dan pesisir. Kota Makassar juga berbatasan secara administratif dengan Kabupaten Maros, Kabupaten Gowa, dan Kabupaten Takalar, dimana ketiga kabupaten tersebut dan daerahdaerah lainnya merupakan daerah penyuplai sumber daya perikanan dan pertanian.

\section{Diagram Sistem}

Sumber daya alam atau energi yang termanfaatkan (useful energy) dan aktifitas masyarakat (human activity) merupakan dua komponen utama yang berperan penting dalam proses metabolisme di kota pesisir. Komponen sumber daya terbarukan seperti matahari, air sungai dan laut, angin, hujan merupakan jenis sumber daya terbarukan primer dalam sistem dan dimasukkan dalam perhitungan emergi. Komponen primer tersebut mengalir dan sebagian terdeposit dalam air dan tanah yang kemudian terkonversi dalam bentuk energi sumber daya perikanan darat dan laut, peternakan, pertanian dan perkebunan, yang merupakan komponen sumber daya alam yang paling maksimal termanfaatkan oleh masyarakat perkotaan dan menjadi proses transformasi utama dalam sistem. Sementara proses transformasi sekunder (industri manufaktur, jasa dan perdagangan, ekspor impor, transportasi, dan pembuangan) menjadi katalis utama dalam proses feedback autocatalytic (Gambar 3).

Nelayan, petani, buruh, wisatawan, dan masyarakat umum lainnya menjadi penggerak/ interaktor utama (hexagons) yang memanfaatkan dan mengelola sumber daya yang tersedia (avalaible energy), sedangkan pemerintah sebagai aktor regulator yang mengelola dan meregulasi proses ekploitasi sumber daya, proses sirkulasi, dan interaksi di dalam sistem.

Dalam proses metabolisme sosial di Kota Makassar, stabilisasi energi baik untuk pemenuhan kebutuhan energi masyarakat dan juga untuk memperkuat proses aliran, diperlukan bantuan penggerak dari luar (purchase) yang diimpor seperti bahan bakar dan listrik (fuels \& electricity), barang dan jasa (goods \& services), makanan dan air (foods \& water), dan tenaga kerja (labour/jobs).

Selanjutnya adalah memberikan hubungan antar komponen melalui jalur pertukaran dan aliran sumber daya yang terjadi, baik dari dalam maupun luar sistem. Bujursangkar besar merupakan batasan sistem yang diteliti, dimana dalam batasan sistem yang digunakan adalah batas wilayah administrasi Kota Makassar sebuah kota pesisir. Diagram yang ditunjukkan mendeskripsikan sintetik tentang arus sumber daya dan proses transformasi yang terjadi di wilayah Kota Makassar, dimana dijelaskan hubungan antara komponen dalam sistem dan luar sistem yang

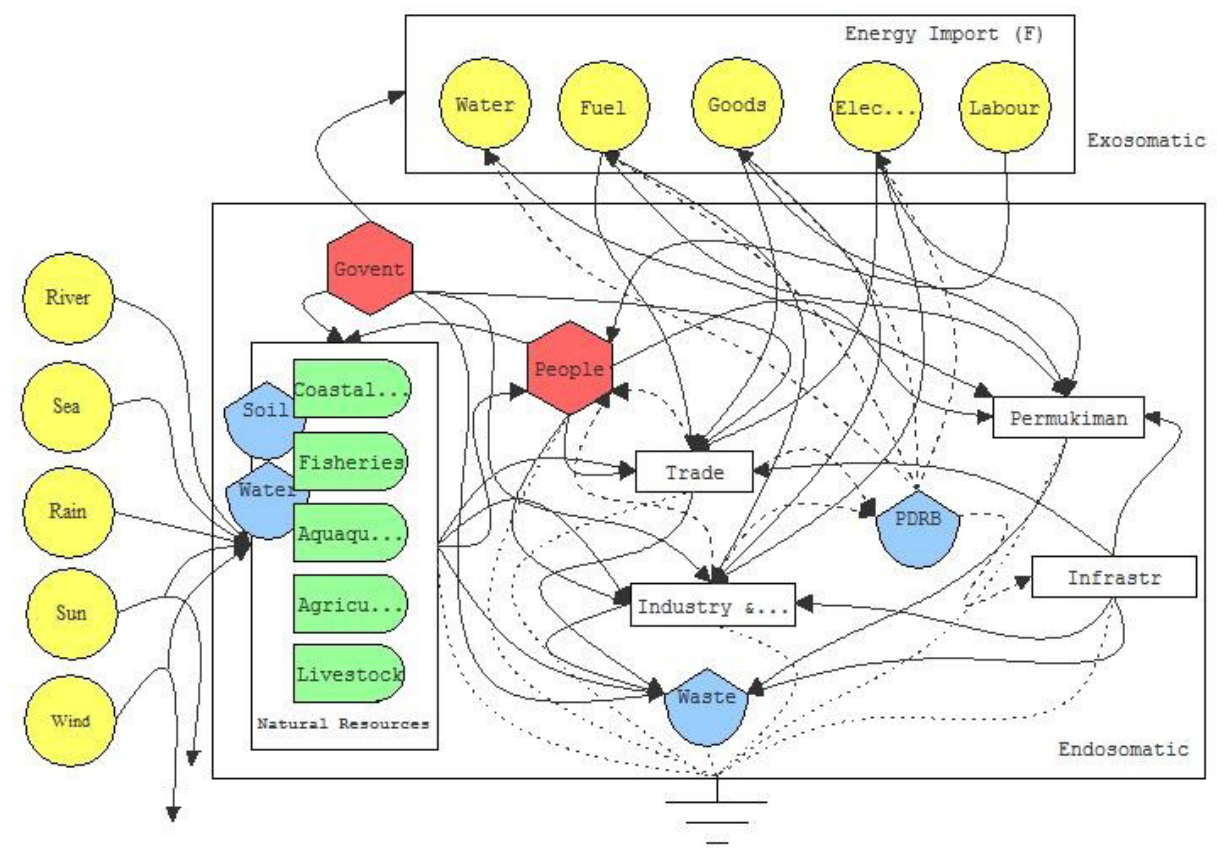

Gambar 3. Diagram Emergi dari Siklus Metabolisme Kota Pesisir, Kota Makassar. 
membentuk pola feedback autocatalytic, serta di antara bagian-bagiannya itu sendiri telah diterjemahkan dalam bentuk aliran energi dan material.

\section{Tabel Emergi Metabolisme Kota Pesisir}

Energi sumber daya yang termanfaatkan di Kota Makassar dikelaskan ke dalam beberapa kelas, di antaranya kelas sumber daya terbarukan, sumber daya non-terbarukan, dan sumber daya yang diimpor. Data tersebut dihimpun selama kurun interval waktu 7 tahun dari 2001, 2003, 2006, 2008, 2011, 2013 dan 2015. Materi dan energi yang bersiklus dalam sistem dibatasi pada data statistik produksi sumber daya lokal terbarukan, seperti produksi tanaman bahan makanan, produksi tanaman sayur-sayuran, produksi tanaman buah-buahan, produksi tanaman perkebunan, produksi hasil peternakan, dan produksi hasil perikanan. Materi dan energi non terbarukan yang digunakan masyarakat (konsumen) dibatasi pada sumber daya air bersih yang dikonsumsi dan ketersediaan sumber daya lahan. Sedangkan sumber daya yang didatangkan dari luar sistem, dibatasi pada penggunaan bahan bakar, konsumsi listrik, dan tenaga kerja (Tabel 3).

Sumber daya primer terbarukan seperti matahari, pasang surut air laut, angin, hujan, dan siklus bumi menjadi parameter yang menentukan eksistensi sumber daya dan lingkungan melalui siklus iklim dan cuaca. Dengan intensitas cahaya matahari tropis dengan angin dan curah hujan yang menyirami wilayah darat dan laut Kota Makassar yang memiliki luas laut sebesar 96.600 hektar dan darat 17.577 hektar, menjadi jaminan kekayaan sumber daya perikanan dan pertanian yang menopang kehidupan masyarakatnya.

Total produksi sumber daya terbarukan (R) mengalami penurunan sejak tahun 2001 hingga 2015. Penurunan sumber daya pesisir terbarukan disebabkan oleh penurunan produksi sumber daya perikanan khususnya budidaya tambak, dan sumber daya hasil pertanian. Demikian juga dengan keberadaan sumber daya tidak terbarukan seperti air minum dan sumber daya lahan, juga mengalami penurunan yang

Tabel 3.

Emergi Sintetik dari Siklus Metabolisme Kota Pesisir Makassar

\begin{tabular}{|c|c|c|c|c|c|c|c|c|}
\hline \multirow{2}{*}{ No } & \multirow{2}{*}{ Item } & \multicolumn{7}{|c|}{ Solar Emergy (E20 sej) } \\
\hline & & 2001 & 2003 & 2006 & 2008 & 2011 & 2013 & 2015 \\
\hline \multicolumn{9}{|c|}{ Renewable Resources (R) } \\
\hline 1 & Sunlight & 0,037 & 0,037 & 0,037 & 0,037 & 0,037 & 0,037 & 0,037 \\
\hline 2 & Rain, chemical & 0,206 & 0,202 & 0,254 & 0,289 & 0,239 & 0,228 & 0,287 \\
\hline 3 & Rain, geopotential & 0,029 & 0,029 & 0,036 & 0,041 & 0,034 & 0,033 & 0,041 \\
\hline 4 & Wind, kinetic energy & 0,004 & 0,009 & 0,016 & 0,016 & 0,009 & 0,009 & 0,002 \\
\hline 5 & Tide & 3,769 & 3,769 & 3,769 & 3,769 & 3,769 & 3,769 & 3,769 \\
\hline 6 & Earth Cycle & 0,148 & 0,148 & 0,148 & 0,148 & 0,148 & 0,148 & 0,148 \\
\hline \multicolumn{9}{|c|}{ Indigenous Renewable Energy (R1) } \\
\hline 7 & Agriculture Production & 0,941 & 0,529 & 0,955 & 1,133 & 1,003 & 0,925 & 0,662 \\
\hline 8 & Livestock Production & 1,897 & 1,249 & 0,851 & 0,447 & 0,597 & 0,659 & 0,611 \\
\hline 9 & Fisheries Production & 1,851 & 2,578 & 2,171 & 2,06 & 1,84 & 1,816 & 1,937 \\
\hline & Total R & 8,882 & 8,550 & 8,237 & 7,940 & 7,676 & 7,624 & 7,494 \\
\hline \multicolumn{9}{|c|}{ Nonrenewable Resources (N) } \\
\hline 10 & Soil losses & 1,866 & 1,687 & 1,507 & 1,465 & 1,424 & 1,254 & 1,084 \\
\hline 11 & Topsoil losses & 0,056 & 0,05 & 0,045 & 0,044 & 0,043 & 0,037 & 0,032 \\
\hline 12 & Water for Consumption & 0,0093 & 0,0096 & 0,01006 & 0,0115 & 0,0116 & 0,0132 & 0,0135 \\
\hline & Total N & 1,931 & 1,747 & 1,562 & 1,521 & 1,479 & 1,304 & 1,129 \\
\hline \multicolumn{9}{|c|}{ Imports And Outside Sources (F) } \\
\hline 13 & Fuels & 0,235 & 0,302 & 0,369 & 0,492 & 0,633 & 0,789 & 0,969 \\
\hline 14 & Electricity & 5,767 & 7,396 & 7,418 & 7,440 & 9,329 & 9,663 & 10,584 \\
\hline \multirow[t]{4}{*}{15} & Labour & 0,019 & 0,0232 & 0,028 & 0,0317 & 0,0389 & 0,0462 & 0,0494 \\
\hline & Total F & 6,021 & 7,721 & 7,815 & 7,963 & 10,001 & 10,498 & 11,602 \\
\hline & $\mathrm{U}=(\mathbf{R}+\mathbf{N}+\mathbf{F})$ & 16,834 & 18,018 & 17,614 & 17,424 & 19,155 & 19,426 & 20,226 \\
\hline & $U * 20 E$ Sej & $1,68 \mathrm{E}+$ & $11,80 \mathrm{E}+$ & $11,76 \mathrm{E}+21$ & $11,74 \mathrm{E}+2$ & $11,92 \mathrm{E}+2$ & $11,94 \mathrm{E}+2$ & $12,02 \mathrm{E}+21$ \\
\hline
\end{tabular}

Sumber: Hasil Analisis (2016) 
signifikan. Penurunan produksi dan eksistensi sumber daya tersebut merupakan implikasi dari meningkatnya jumlah penduduk dengan segala kebutuhannya, seperti lahan usaha dan permukiman, kebutuhan konsumsi pangan, dan kebutuhan sandang lainnya. Beda halnya dengan sektor energi tidak terbarukan, khususnya barang impor seperti bahan bakar dan listrik justru mengalami peningkatan pembelian.

Nilai total emergi dari tahun 2001 hingga 2015 berfluktuatif, dimana nilai emergi pada 2008 mengalami penurunan khususnya pada nilai R1 yaitu pada produksi sektor pertanian dan peternakan Penurunan nilai produksi pada sektor pertanian dan peternakan mungkin saja disebabkan oleh terjadinya cuaca ekstrim yang diindikatori oleh meningkatnya suhu, angin, dan hujan pada tahun-tahun tersebut. Nilai $U$ menggambarkan besarnya energi yang dibutuhkan untuk menunjang aktifitas masyarakat di Kota Makassar. Nilai U juga menunjukkan besarnya intervensi manusia terhadap keberadaan sumber daya lahan, bagaimana manusia mengelolanya, bagaimana manusia memanfaatkannya, dan bagaimana usaha manusia berupaya menstabilkan proses sistem sehingga dapat terus berdaptasi dengan perubahan lingkungan dan bertahan hidup dalam minimnya sumber daya lokal. Dengan kata lain, meningkatnya total emergi yang mengalir dalam sistem kota pesisir, khususnya Kota Makassar mengakibatkan tekanan terhadap ketersediaan lahan kosong atau lahan-lahan yang digunakan pada sektor perikanan dan pertanian.

Semua sumber daya tersebut, baik sumber daya lokal maupun impor menjadi pendukung kestabilan operasional sistem perkotaan. Aliran emergi yang tersendat akan mempengaruhi proses metabolisme secara keseluruhan, namun aliran emergi yang besar juga akan menjadi faktor penyebab meningkatnya aktifitas manusia yang berimbas pada pemanfatan lahan yang semakin tinggi pula.

Sumber daya terbarukan $(R)$ dalam penelitian ini dibatasi pada beberapa komponen yaitu sumber daya terbarukan primer seperti matahari, angin, dan hujan. Sedangkan sumber daya terbarukan lainnya adalah sektor perikanan, peternakan dan pertanian. Dari data multi series, terlihat bahwa nilai $\mathrm{R}$ dari tahun ke tahun relative stabil, terjadinya penurunan produksi bisa saja disebabkan oleh faktor peningkatan konversi area terbuka yang memiliki fungsi pertanian dan perkebunan, dan iklim yang diindikatori oleh ketidakstabilan variable hujan dan angin.

Hasil perhitungan emergi menggambarkan dinamika siklus pemanfaatan sumber daya di Kota Makassar yang pada 2001, kebutuhan energi sumber daya masih didominasi oleh keberadaan sumber daya alam lokal dan masih mengalahkan pembelian sumber daya. Namun pada tahun-tahun berikutnya produksi sumber daya alam lokal semakin menurun seiring meningkatnya kebutuhan masyarakat akibat peningkatan jumlah populasi dan meningkatnya area terbangun. Peningkatan jumlah penduduk berdampak pada semakin besarnya kebutuhan energi sumber daya oleh masyarakat baik untuk kebutuhan konsumsi maupun untuk produksi. Dan untuk memenuhi kekurangan energi sumber daya tersebut, maka dilakukan pembelian sumber daya dari luar (purchase/ import). Energi sumber daya yang diimpor terutama diperoleh dari bahan bakar minyak dan gas serta listrik.

Wilayah laut Kota Makassar yang cukup luas dan berada pada kawasan Kepulauan Spermonde dan Selat Makassar tentunya kaya akan sumber daya perikanan, hal tersebut ditunjukkan dari nilai produksi perikanan yang relatif stabil. Khusus untuk produksi perikanan, nilai emergi banyak diperoleh dari sektor perikanan tangkap. Sedangkan untuk perikanan tambak, produksinya semakin menurun seiring semakin menipisnya lahan tambak yang tersedia. Sedangkan pada sector perikanan tangkap, intervensi lahan tidak sebesar pada sector pertanian dan budidaya tambak.

Untuk sumber daya tidak terbarukan (N), air untuk kebutuhan konsumsi dikategorikan sebagai sumber daya tidak terbarukan, hal tersebut disebabkan oleh semakin menipisnya cadangan air tanah akibat meningkatnya kebutuhan air untuk konsumsi dan intrusi air laut. Intrusi air laut adalah proses masuknya air laut mengganti air tawar yang ada dalam tanah, atau proses masuk atau menyusupnya air laut ke dalam pori-pori batuan dan mencemari air tanah yang terkandung di dalamnya (Annisa et al,, 2015). Penyebab intrusi lainnya adalah berkurangnya area terbuka hijau, khususnya vegetasi mangrove di sepanjang pantai dan pulau-pulau kecil di Kota Makassar. Dan untuk menutupi kekurangan air bersih di Kota Makassar, maka PDAM Kota Makassar melakukan impor air bersih dari Sungai Jeneberang Kabupaten Gowa dan Sungai Lekopancing Kabupaten Maros (PDAM Kota Makassar).

Untuk sumber daya jasa (services), penelitian difokuskan pada kaum urban yang datang ke Kota Makassar sebagai pencari kerja. Berkembangnya sektor industri, perdagangan, dan perhotelan, tentunya membutuhkan tenaga kerja yang banyak, sedangkan tenaga kerja lokal tidak mampu atau tidak memiliki kompetensi yang cukup. Sebagai pusat perekonomian di Indonesia Timur, Kota Makassar. Dalam metabolisme emergi, tenaga kerja (labour) dikategorikan sebagai input dari luar sistem atau tenaga kerja dianggap sebagai komponen luar yang mengintervensi metabolisme emergi yang terjadi dalam sistem kota pesisir. Jenis mata pencaharian yang ada di Kota Makassar terdiri atas nelayan, petani, 
peternak, PNS, pedagang, karyawan/buruh. Pada 2001 ke bawah mata pencaharian yang berkaitan dengan pemanfaatan sumber daya lahan pesisir masih didominasi oleh kegiatan bertambak, nelayan, dan bertani.

Banyaknya investasi di sektor industri, perdagangan, jasa, dan perhotelan berdampak pada besarnya kebutuhan tenaga kerja. Tentunya kondisi ini memancing datangnya pendatang (urban) dari luar daerah untuk datang dan mencari nafkah di Kota Makassar. Jumlah pendatang dari tahun ke tahun semakin meningkat dan menambah jumlah populasi yang ada di Kota Makassar. Sebagai contoh, sektor perdagangan, mampu menyerap pasar tenaga kerja sebesar 34,24 \% dari total 904.644 penduduk usia kerja berdasarkan data survei Sosial Ekonomi Nasional (Sensus, 2000).

\section{Nilai Emergi Berdasarkan Sistem Evaluasi Metabolime Perkotaan}

Untuk memprediksi kelangsungan hidup ekonomi, daya dukung, atau stabilitas sistem, dilakukan perhitungan indeks emergi yang berhubungan dengan arus emergi dari sistem kota pesisir yang sedang dievaluasi. Dalam penelitian ini, untuk mengevaluasi dan menilai keberlanjutan metabolisme emergi dari Kota Makassar, maka digunakan 6 indeks berdasarkan perhitungan indeks yang dilakukan oleh Qing et al. (2015) (Tabel 4).

Nilai indeks St1 (Struktur 1) memberi gambaran pola konsumsi energi sumber daya dari masyarakat kota pesisir. Dalam kurun waktu 14 tahun, nilai I berada di atas $80 \%$ yang mengindikasikan bahwa masyarakat Kota Makassar masih mengkonsumsi sendiri sumber daya terbarukan $(R)$ seperti produksi perikanan dan pertanian dalam proses pembangunan perkotaan. Nilai tersebut juga menunjukkan bahwa nilai $\mathrm{R}$ atau sumber daya alam terbarukan seperti produksi perikanan dan pertanian masih mampu memenuhi kebutuhan masyarakatnya.

Nilai Struktur St2 berada pada kisaran pada 2001 masih menunjukkan nilai yang relatif tinggi yaitu $11 \%$, namun pada tahun-tahun berikutnya hingga pada akhir 2015 menunjukkan tren penurunan hingga menyentuh tingkat $5 \%$. Hal tersebut menunjukkan fakta bahwa sumber daya daya tidak terbarukan $(N)$ seperti air untuk konsumsi dan sumber daya lahan semakin langka dan menunjukkan tingkat konversi lahan dan penggunaan air yang berlebihan. Sebagaimana WHO telah menstandarkan jumlah kebutuhan air untuk kebutuhan masyarakat kota metropolitan (domestic use) adalah sebesar 185 liter/orang/hari. Berdasarkan jumlah kebutuhan air tersebut, Kota Makassar setidaknya membutuhkan cadangan air sebesar 286.369.042,44 liter pada 2015. Berdasarkan data konsumsi air di Kota Makassar pada 2015 sebesar 187.944.853.232 liter. Nilai konsumsi tersebut menunjukkan bahwa Kota Makassar sudah berlebihan dalam mengkonsumsi air.

Nilai Struktur S3 pada kurun waktu 15 tahun menunjukkan nilai persentase sekitar $35 \%$ pada awal tahun 2000an dan terus meningkat hingga $57 \%$ pada 2015. Nilai persentase tersebut menunjukkan bahwa pada 2000an awal, sumbangsih atau kebutuhan masyarakat akan sumber daya impor belumlah banyak karena kemampuan nilai $\mathrm{R}$ (sumber daya terbarukan) masih mampu memenuhinya, namun seiring pertambahan penduduk dan semakin menurunnya produksi $\mathrm{R}$, maka kebutuhan energi tambahan dari luar semakin besar, dan berada pada tingkat dimana energi sumber daya impor menjadi kebutuhan yang urgen dan mempengaruhi proses metabolisme sistem secara keseluruhan.

Nilai Intensity (I) atau Emergy per Person (EpP) adalah rasio total emergi dengan populasi. Indeks ini menunjukkan bagaimana konsumsi terkait dengan populasi lain, dalam arti lain, indeks ini merupakan tanggung jawab setiap penduduk dalam penggunaan sumber daya. Hasil analisis menunjukkan bahwa nilai

Tabel 3.

Emergi Sintetik dari Siklus Metabolisme Kota Pesisir Makassar

\begin{tabular}{lllllllll}
\hline & \multicolumn{7}{c}{ Nilai } & \\
\cline { 2 - 6 } Indeks & 2001 & 2003 & 2006 & 2008 & 2011 & 2013 & 2015 & Unit \\
\hline St1 & 0,821 & 0,830 & 0,841 & 0,839 & 0,838 & 0,854 & 0,869 & \\
St2 & 0,115 & 0,097 & 0,089 & 0,087 & 0,077 & 0,067 & 0,056 & $\%$ \\
St3 & 0,358 & 0,429 & 0,444 & 0,457 & 0,522 & 0,540 & 0,574 & $\%$ \\
I & $1,51 \mathrm{E}+$ & $1,57 \mathrm{E}+$ & $1,45 \mathrm{E}+$ & $1,39 \mathrm{E}+$ & $1,42 \mathrm{E}+$ & $1,38 \mathrm{E}+$ & $1,31 \mathrm{E}+$ & Sej/Pop \\
& 15 & 15 & 15 & 15 & 15 & 15 & 15 & \\
EmRp & $2,21 \mathrm{E}+$ & $2,03 \mathrm{E}+$ & $1,55 \mathrm{E}+$ & $1,28 \mathrm{E}+$ & $1,07 \mathrm{E}+$ & $9,11 \mathrm{E}+$ & $2,28 \mathrm{E}+$ & Sej/Rp \\
& 08 & 08 & 08 & 08 & 08 & 07 & 07 & \\
W & 0,025 & 0,024 & 0,026 & 0,027 & 0,027 & 0,028 & 0,029 & $\%$ \\
\hline
\end{tabular}

Sumber: Hasil Analisis 2016 
I cenderung mengalami penurunan konsumsi emergi per satu jiwa penduduk sejak 2001 di Kota Makassar. Rasio yang relatif menurun menunjukkan bahwa kompetisi di masyarakat semakin meningkat akibat meningkatnya jumlah penduduk dan kebutuhan lahan. Nilai tersebut juga mengindikasikan menurunnya kesejahteraan masyarakat pada 2015 dibandingkan pada 2001.

Nilai emergi rupiah atau rasio emergi untuk uang diperoleh dengan membagi penggunaan emergi total suatu wilayah dengan produk domestik regional bruto. Hasilnya adalah rata-rata jumlah emergi yang dibeli dengan menghabiskan satu rupiah (sej/rupiah). Nilai yang diperoleh menunjukkan bahwa daya beli rupiah terhadap kekayaan ril (emergy) dari tahun ke tahun semakin menurun.

Berdasarkan data dari 2001 hingga 2015, terjadi peningkatan jumlah produksi sampah seiring meningkatnya jumlah penduduk dan meningkatnya jumlah bangunan industri yang dibangun. Rasio emisi limbah (W) dari 2001-2015 cenderung mengalami peningkatan. Hal tersebut mengindikasikan bahwa lingkungan sistem telah mengalami tekanan akibat peningkatan area terbangun yang mengkonversi area terbuka serta meningkatnya jumlah penduduk dengan segala aktifitasnya baik domestik maupun industry di Kota Makassar. Sampah sudah menjadi masalah serius di Kota Makassar. Berdasarkan data produksi sampah di Kota Makassar, produksi sampah padat (solid waste) di Kota Makassar, menghasilkan kirakira $4000 \mathrm{~m}^{3}$ atau 550 ton per hari atau 1.460.000 $\mathrm{m}^{3}$ per tahun (Dinas Kominfo Kota Makassar, 2015), sedangkan dari sampah cair (liquid waste) dihasilkan limbah sebesar $1.300 .000 \mathrm{~m}^{3}$ per tahun.

\section{Status Keberlanjutan Metabolisme Emergi Berdasarkan Evaluasi Penggunaan Lahan di Kota Pesisir}

Kota Makassar sebagai kota yang terletak di wilayah pesisir tentu memiliki kondisi penggunaan lahan yang sangat dipengaruhi oleh dinamika laut dan pesisir, dan oleh aktifitas mayoritas masyarakatnya yang turun temurun sebagai nelayan, petambak, dan petani. Posisi yang strategis dan menjadi pintu masuk barang dari luar ke wilayah Makassar dan Indonesia Timur pada umumnya, menjadikan Kota Makassar cepat berkembang baik ekonomi maupun populasinya. Peningkatan ekonomi menjadi daya tarik dan penyebab meningkatnya jumlah penduduk di Kota Makassar. Peningkatan jumlah penduduk menjadikan lahan yang ada semakin menyempit disebabkan oleh meningkatnya kebutuhan dan permintaan akan lahan kosong (area terbuka).

Kondisi tersebut di atas tentu saja mempengaruhi pola aliran energi, dimana perubahan penggunaan lahan tentu saja mengubah fungsi lahan itu sendiri. Sebagai contoh, lahan pertambakan atau lahan pertanian yang semula berfungsi sebagai lahan produksi perikanan dan pertanian dan menjadi sumber daya terbarukan, setelah beralih fungsi menjadi lahan industri atau permukiman, kekosongan sumber daya terbarukan (R) tersebut tentu saja akan diisi oleh sumber daya dari sumber yang lain, semisal impor atau pembelian dari daerah lain. Olehnya itu, sangat penting meninjau status keberlanjutan energi sumber daya terbarukan, sehingga diketahui sejauh mana peran sumber daya lokal terhadap keberlanjutan sistem kota pesisir, dalam hal ini Kota Makassar.

Untuk mengetahui status keberlanjutan metabolisme emergi yang didasarkan pada pemanfaatan sumber daya lahan di Kota Pesisir, maka digunakan empat indeks, yaitu Empower Density (ED), Environment Loading Ratio (ELR), Emergy Sustainable Indice (ESI), dan Emergy Yield Ratio (EYR) (Tabel 5).

Empower Density (ED) menunjukkan tingkat kekayaan dan potensi sumber daya dalam suatu wilayah. Bisa juga ED mengindikasikan tingkat kesejahteraan ekonomi wilayah atau sistem. Kota Makassar yang terletak di wilayah pesisir dan memiliki luas laut dan pulau-pulau kecil menjadi poin tersendiri dan aset yang potensial untuk dikembangkan lebih baik ke depannya. Posisi yang strategis dengan sumber daya perikanan yang melimpah menjadikan proses dalam siklus sistem menjadi lebih stabil dan sustain.

Tabel 5.

Indeks Emergi Penggunaan Lahan dari Siklus Metabolisme Sosial Ekologi Kota Pesisir, Kota Makassar

\begin{tabular}{llllllll}
\hline \multirow{2}{*}{ Indeks } & \multicolumn{7}{c}{ Nilai } \\
\cline { 2 - 8 } & $\mathbf{2 0 0 1}$ & $\mathbf{2 0 0 3}$ & $\mathbf{2 0 0 6}$ & $\mathbf{2 0 0 8}$ & $\mathbf{2 0 1 1}$ & $\mathbf{2 0 1 3}$ & $\mathbf{2 0 1 5}$ \\
\hline ED & $1,47 \mathrm{E}+16$ & $1,58 \mathrm{E}+16$ & $1,54 \mathrm{E}+16$ & $1,53 \mathrm{E}+16$ & $1,68 \mathrm{E}+16$ & $1,70 \mathrm{E}+16$ & $1,77 \mathrm{E}+16$ \\
EYR & 2,80 & 2,33 & 2,25 & 2,19 & 1,92 & 1,85 & 1,74 \\
ESI & 3,12 & 2,11 & 1,98 & 1,83 & 1,28 & 1,20 & 1,03 \\
ELR & 0,90 & 1,11 & 1,14 & 1,19 & 1,50 & 1,55 & 1,70 \\
EIR & 0,56 & 0,75 & 0,80 & 0,84 & 1,09 & 1,18 & 1,35 \\
\hline Sinber:
\end{tabular}

Sumber: Hasil Analisis (2016). 
Nilai ED yang diperoleh sekitar 1,47E+16 Sej/Area pada 2001 terus mengalami peningkatan hingga pada tahun 2015 diperoleh nilai ED sekitar 1,77E+16 Sej/ Area. Peningkatan nilai ED tersebut mengindikasikan maksimalnya pemanfaatan lahan sumber daya di wilayah tersebut. Selain diperoleh melalui produksi sumber daya lokal ( $R$ dan $N$ ), juga karena terjadi peningkatan jumlah pembelian sumber daya dari luar sistem. Peningkatan rasio ED di Kota Makassar juga mengindikasikan bahwa peningkatan jumlah lahan terbangun yang dibarengi dengan peningkatan arus emergi mengindikasikan pertumbuhan area industri, perdagangan dan jasa yang baru. Perkotaan dengan sistem industri, perkembangan bisnis komersial dan pembangunan perumahan dengan kepadatan yang tinggi memiliki arus emergi masuk yang tinggi dan ini berarti bahwa ED lebih tinggi dibandingkan dengan ED di perdesaan (Haden, 2003).

Emergy Yield Ratio (EYR) merupakan rasio dari total input emergi dan total output emergi. Brown \& Ulgiati (1997) dalam Djau (2012) menjelaskan bahwa EYR merupakan indikator dari proses hasil emergi lokal dan mengukur proses tersebut dalam mengeksploitasi sumber daya lokal. Nilai terendah dari EYR adalah 1, yang menunjukkan bahwa suatu proses yang sama dengan emergi yang tersedia dan dianggap tidak berkontribusi dalam mengeksploitasi suatu sumber daya lokal, atau nilai EYR yang kurang dari 1 menunjukkan bahwa sistem yang bekerja tidak berkelanjutan (Voora \& Thrift, 2010). EYR >1 atau <2 tidak memberikan emerg bersih yang signifikan bagi perekonomian dan hanya memproses sumber daya lokal yang tersedia. EYR pada kisaran $>2$ dan $<5$ menunjukkan bahwa sumber daya energi baik sekunder maupun primer masih memberikan kontribusi yang seimbang terhadap perekonomian. Dan nilai EYR $>5$ menunjukkan sumber energi primer dan memiliki manfaat dan berkontribusi terhadap perekonomian.

Berdasarkan hasil analisis emergi sintetik, nilai EYR yang diperoleh pada 2001 hingga 2008, nilai EYR masih dikisaran $>2$ dan $<5$, yang artinya bahwa produksi baik lokal maupun impor masih mampu memberikan kontribusi yang seimbang terhadap perkembangan perekonomian Kota Makassar. Keseimbangan tersebut berarti juga bahwa sistem dengan keberadaan sumber dayanya baik di daratan pesisir maupun di laut, masih mampu memberikan konstribusi pada siklus dan proses metabolisme social ekologi hingga pada taraf berkelanjutan. Namun di atas tahun 2008 hingga pada tahun 2015, nilai EYR menunjukkan tren penurunan hingga di bawah $<2$, yang berarti bahwa aliran sistem sudah menunjukkan ketidakseimbangannya. Kondisi tersebut sangat memungkinkan karena pertumbuhan jumlah penduduk yang signifikan dibarengi dengan pertumbuhan jumlah lahan terbangun yang mengkonversi sebagian lahan-lahan perikanan dan pertanian, sehingga mengakibatkan tidak berimbangnya jumlah produksi lokal maupun impor terhadap keseimbangan siklus social metabolism kota pesisir.

Emergy Sustainable Indice (ESI) merupakan rasio perbandingan hasil panen emergi terhadap rasio beban lingkungan. Ukuran tersebut mengasumsikan bahwa fungsi dari tujuan untuk keberlanjutan adalah mendapatkan perbandingan dengan produksi yang tinggi dan meminimalkan beban terhadap lingkungan (Brown \& Ulgiati, 1998). Nilai yang lebih tinggi menunjukkan lebih banyak manfaat sosial ekonomi per unit tekanan beban lahan dan pemanfaatan lahan yang lebih berkelanjutan. Berdasarkan kriteria oleh Brown \& Ulgiati. (1998), nilai ESI<1 menjadi indikasi dari suatu sistem ekonomi perkotaan berbasis konsumen atau orientasi konsumen dalam suatu sistem yang sangat berkembang. ESI>1 mengindikasikan bahwa produk memiliki kontribusi bersih terhadap masyarakat dan relatif perekonomian yang belum berkembang. Sedangkan kisaran ESI antara 1-10 merupakan indikasi suatu negara atau sistem sedang berkembang (Brown \& Ulgiati, 1997). Sedangkan menurut Menurut Cao \& Feng. (2007) dalam Zhang et al. (2010, 2011) bahwa nilai $\mathrm{ESI}<1$ menunjukkan bahwa produk dan proses suatu sistem tidak berkelanjutan. Nilai suatu sistem pada rentang $1<\mathrm{ESI}<5$ menunjukkan bahwa sistem produksi atau suatu proses memiliki keberlanjutan dan berkontribusi terhadap perekonomian untuk jangka menengah, dan produk atau proses dengan ESI>5 dapat dianggap berkelanjutan jangka panjang.

Berdasarkan nilai ESI yang diperoleh selama 7 tahun pengamatan, menunjukkan kisaran nilai rata-rata diatas $>1$. Nilai tersebut mengindikasikan bahwa system produksi mampu berkontribusi terhadap perekonomian untuk jangka waktu menengah. Pada awal tahun 2000an, nilai ESI masih di atas 3, yang berarti bahwa sumber daya alam diprediksi masih sangat besar dan mampu memenuhi kebutuhan masyarakat. Namun, nilai ESI hingga tahun 2015 mengalami penurunan yang signifikan hingga mendekati tingkat 1, yang berarti bahwa kondisi tersebut sangat memprihatinkan dan menunjukkan kerapuhan suatu system. Gejala penurunan nilai ESI tersebut memberikan indikasi bagaimana pola konsumsi masyarakat Kota Makassar yang sangat tinggi dan apabila tidak dikendalikan, maka sistem dalam produksi dan proses tidak akan berkelanjutan. Kerapuhan sistem bias terjadi apabila area terbuka yang notabene banyak menjadi area pertanian dan perikanan kemudian dikonversi ke dalam fungsi lahan lain seperti permukiman. Menurunnya area panen menyebabkan menurunnya nilai produksi, dan menurunnya nilai produksi dengan kebutuhan masyarakat yang tidak berimbang berdampak pada 
terjadinya kelangkaan sumber daya, hingga pada akhirnya system kota pesisir akan mencari jalan menuju proses kesimbangan sistemnya, seperti dengan melakukan efisiensi pemanfaatan sumber daya dan atau melakukan impor sumber daya.

ELR (Environment Loading Ratio) merupakan suatu pendekatan untuk mengakses daya dukung sistem produksi. ELR adalah rasio jumlah emergi sumber daya yang terbarukan dan sumber daya yang dibeli dengan emergi sumber daya terbarukan (Brown \& Ulgiati, 1997). Nilai-nilai yang lebih tinggi menunjukkan bahwa beban lingkungan lahan yang lebih tinggi atau semakin tinggi proporsi emergi terbarukan yang digunakan oleh suatu perekonomian, maka semakin rendah nilai ELR-nya. Di sisi lain, ekonomi yang sangat tergantung pada sumber emergi dari luar memiliki nilai ELR yang tinggi. Secara umum indeks ELR memberi gambaran atau ukuran dari stres ekosistem akibat aktifitas ekonomi (Haden dalam Skuladottir 2005). Indeks ELR yang tinggi juga menggambarkan sistem dengan konsumsi sumber daya tak terbarukan yang tinggi atau dengan emisi tinggi (Brown \& Ulgiati, 1997); Cao \& Fang. (2007) in Zhang et al. (2010). Nilai ELR yang tinggi pula berarti bahwa beban atau dampak terhadap lingkungan tinggi. Nilai ELR juga merupakan indikator tekanan suatu proses pada ekosistem lokal dan dapat dianggap sebagai ukuran dari stress ekosistem akibat aktifitas produksi (Ulgiati \& Brown, 1998).

Berdasarkan nilai ELR yang diperoleh dalam 7 tahun pengamatan menunjukkan bahwa aktifitas ekonomi di Kota Makassar masih sangat dipengaruhi oleh besarnya sumber daya lokal yang tersedia dan menunjukkan pula bahwa system belum sepenuhnya tergantung pada pembelian sumber daya dari luar. Sektor perikanan tangkap dan budidaya, serta sektor pertanian masih masih menjadi andalan bagi masyarakat dalam memenuhi kebutuhan primernya. Akan tetapi, nilai ELR tersebut mulai cenderung meningkat dari tahun ke tahun hingga tahun 2015 berada pada kisaran nilai 1,7. Hal tersebut mengindikasikan bahwa beban bagi lingkungan mulai menunjukkan peningkatan dan proses perekonomian serta aktifitas produksi mulai memberikan takanan terhadap ekosistem lokal.

Emergy Investment Ratio (EIR) adalah rasio emergi input eksternal yang dibeli untuk mendukung sistem dalam hubungannya dengan semua emergi lokal, baik terbarukan maupun tidak terbarukan. Indeks ini menunjukkan proporsi investasi terhadap sumber daya ekonomi asli daerah dan mencerminkan intensitas pembangunan (Campbell, 2005). Semakin tinggi nilai EIR maka semakin menunjukkan kerapuha sebuah sistem karena ketergantungan pada masukan dari sistem ekonomi lainnya. Tingkat ketergantungan pada ekosistem yang lain menunjukkan kelemahan dalam kapasitas kompetitif (kemandirian dan keberlanjutan jangka panjang) sebuah system, karena ketersediaan sumber daya untuk pengembangan dan pemeliharaan yang tidak di bawah control system.

Nilai indeks EIR di Kota Makassar menunjukkan intensitas yang relatif rendah yang sesuai antara emergi ekonomi yang dibeli dari luar wilayah dengan emergi dari sumber daya lingkungan terbarukan dan tidak terbarukan dalam wilayah atau sistem. sebagaimana menurut Odum. (1996) tren peningkatan intensitas pembangunan melalui peningkatan investasi terhadap sumber daya lokal dari tahun ke tahun. Berdasarkan nilai ini pula menunjukkan bahwa Kota Makassar masih menjadi tempat yang menarik untuk investasi ekonomi. Namun patut diwaspadai tren peningkatan nilai EIR yang selama kurun waktu 14 tahun semakin meningkat. Hal tersebut mengindikasikan bahwa pasokan energi sumber daya dari dalam system sudah mulai menurun dan tidak berimbang sehingga kebutuhan mulai dipasok dari luar sistem.

\section{KESIMPULAN DAN SARAN}

\section{Kesimpulan}

Berdasarkan uraian di atas, maka dapat disimpulkan bahwa Kota Makassar sebagai kota pesisir telah menjadi sebuah sistem kota pesisir dengan aliran emergy yang cukup besar dan mengalami peningkatan dari tahun ke tahun. Total emergi yang mengalir di 2001 sebesar 1,68E+21 Sej, meningkat menjadi 2,02E+21 Sej pada 2015.

Indeks emergi untuk mengevaluasi proses metabolime Kota Makassar dapat disimpulkan sebagai berikut:

1. Indeks $\mathrm{S} 1$ menunjukkan bahwa $80 \%$ lebih, sistem kota pesisir Makassar masih memanfaatkan sumber daya terbarukan $(R)$ seperti produksi perikanan dan pertanian dalam proses pembangunan perkotaan.

2. Indeks S2 yang diperoleh menunjukkan fakta bahwa sumber daya daya tidak terbarukan $(\mathrm{N})$ seperti air untuk konsumsi dan sumber daya lahan semakin langka akibat tingkat konsumsi air dan konversi lahan yang berlebih.

3. Indeks S3 yang diperoleh menunjukkan bahwa pembangunan dan perkembangan sosial ekonomi Kota Makassar selain memanfaatkan sumber daya lokal, juga mengalami trend pemanfaatan sumber daya impor yang semakin meningkat.

4. Indeks I yang diperoleh menunjukkan kondisi sosial ekonomi masyarakat Kota Makassar yang 
cenderung mengalami penurunan konsumsi emergi per satu jiwa penduduk sejak 2001 di Kota Makassar. Rasio tersebut juga mengindikasikan peningkatan kompetisi pemanfaatan sumber daya.

5. Indeks EmRp menunjukkan bahwa daya beli rupiah terhadap kekayaan ril (emergy) dari tahun ke tahun di Kota Makassar semakin menurun.

6. Indeks W yang diperoleh menunjukkan bahwa lingkungan sistem telah mengalami tekanan akibat peningkatan area terbangun yang mengkonversi area terbuka serta meningkatnya jumlah penduduk dengan segala aktifitasnya baik domestik maupun industri.

Sedangkan Status Keberlanjutan Metabolisme Emergi Berdasarkan Evaluasi Penggunaan Lahan di Kota Pesisir dapat disimpulkan sebagai berikut:

1. Indeks ED yang diperoleh mengindikasikan maksimalnya pemanfaatan lahan sumber daya di Kota Makassar. Peningkatan jumlah lahan terbangun yang dibarengi dengan peningkatan arus emergi mengindikasikan pertumbuhan area industri, perdagangan dan jasa yang baru.

2. Indeks EYR menggambarkan keseimbangan kontribusi sumber daya lokal dan pembelian sumber daya terhadap perkembangan perekonomian Kota Makassar. Keseimbangan tersebut berarti juga bahwa system dengan keberadaan sumber dayanya baik di daratan pesisir maupun di laut, masih mampu memberikan konstribusi pada siklus dan proses metabolisme sosial ekologi hingga pada taraf berkelanjutan.

3. Indeks ESI di Kota Makassar menunjukkan kemampuan produksi energi sumber daya berkontribusi terhadap perekonomian dalam jangka waktu menengah di awal tahun 2000an, namun 14 tahun kemudian menunjukkan gejala penurunan hingga mendekati tingkat 1 , yang berarti bahwa kondisi tersebut sangat memprihatinkan dan menunjukkan kerapuhan sistem kota pesisir Makassar.

4. Indeks ELR yang diperoleh menunjukkan bahwa sumber daya lokal masih sangat mempengaruhi aktifitas ekonomi di Kota Makassar di awal tahun 2000an serta menunjukkan bahwa system belum sepenuhnya tergantung pada pembelian sumber daya dari luar. Namun, 14 tahun berjalan, indeks ELR cenderung mengalami peningkatan. Hal tersebut mengindikasikan bahwa beban bagi lingkungan mulai menunjukkan peningkatan dan proses perekonomian serta aktifitas produksi mulai memberikan takanan terhadap ekosistem lokal.

5. Indeks EIR di Kota Makassar menunjukkan intensitas yang relatif rendah yang sesuai antara emergi ekonomi yang dibeli dari luar wilayah dengan emergi dari sumber daya lingkungan terbarukan dan tidak terbarukan dalam wilayah atau sistem. Indeks EIR juga menunjukkan bahwa Kota Makassar masih menjadi tempat yang menarik untuk investasi ekonomi. Namun patut diwaspadai peningkatan indeks EIR yang menunjukkan trend peningkatan. Peningkatan indeks EIR tersebut mengindikasikan penurunan pasokan energi sumber daya dari dalam sistem, sehingga sehingga kebutuhan mulai dipasok dari luar sistem.

\section{Saran}

Metode pemanfaatan energi berbasis perhitungan emergi relatif sulit untuk digunakan. Semua rincian data dan gambaran holistik dari suatu wilayah dapat dibuat dengan menggabungkan banyak sisi yang berbeda dari sistem ekonomi dan lingkungan yang ada. Keberlanjutan basis emergi merupakan transdiciplinary, dimana sangat diperlukan berbagai sudut pandang dari disiplin ilmu yang berbeda untuk dapat mengukur emergi dengan cara yang lebih akurat dan dapat dipertanggungjawabkan.

Data yang digunakan dalam penelitian ini masih sangat sederhana, yaitu hanya menggunakan data yang sebagian besar merupakan data-data statistik dari berbagai sumber. Untuk melakukan perhitungan sumber daya berbasis emergi, sebaiknya data input harus didapatan secara terperinci, dan ini tentunya membutuhkan banyak waktu, biaya, dan kehati-hatian.

\section{PERSANTUNAN}

Penelitian ini merupakan bagian dari kegiatan penelitian yang berjudul "Kajian Dampak Penambangan Pasir Laut Pantai Utara Banten untuk Reklamasi Teluk Jakarta Terhadap Sumber Daya Laut dan Pesisir" yang dibiayai dari DIPA Pusat Penelitian dan Pengembangan Sumber Daya Laut dan Pesisir Tahun 2014. Ucapan terima kasih yang sebesar-besarnya disampaikan kepada Dinas Kelautan, Perikanan, Energi, dan Sumber Daya Mineral khususnya kepada Bapak Kepala Dinas, Ibu Mumun Munawaroh, M.Sc dan staf. Ucapan terima kasih juga disampaikan kepada Pak Edi Kusmanto, Pak Muhadjirin, dan Pak Priyadi Dwi Santoso yang juga turut membantu dalam pengambilan data peneltian ini di lapangan. Tidak lupa ucapan terima kasih disampaikan kepada reviewer yang telah menjadikan tulisan ini layak untuk diterbitkan.

\section{DAFTAR PUSTAKA}

Annisa, D.D., Muhammad, A.T. \& Ardy, A. (2015). Studi Salinitas Air Tanah Dangkal Di Daerah Pesisir Bagian Selatan Kota Makassar. Program Studi Teknik Lingkungan Jurusan teknik Sipil, 
Universitas Hasanuddin.

Eurostat. (1999). Towards environmental pressure indicators for the EU. Office for Official Publications of the European Communities, Luxembourg.

Giampietro, M. \& Kozo, M. (2000). Multiple-Scale Integrated Assessment of Societal Metabolism: Introducing the Approach. Population and Environment: A Journal of Interdisciplinary Studies Volume 22.

Haberl, H., Erb, K.H., Krausmann, F., Loibl, W., Schulz, N. \& Weisz, H. (2001). Changes in ecosystem processes induced by land use: human appropriation of net primary production and its influence on standing crop in Austria. Global Biogeochem. Cycles 15, 929-942.

Kennedy, C.A., Cuddihy, J. \& Engel, Y.J. (2007). The changing metabolism of cities. Journal of Industrial Ecology 2007 (11), 43-59.

Odum, H.T. (1996). Environtmental Accounting: Emergy and Environmental Policy Making. John Wiley and Sons, New York.

Ulgiati, S. \& Brown, M.T. (1998). Monitoring Patterns of Sustainability in Natural and Man-made Ecosystems. Ecol. Model. 108, 23-26.

Voora, V. \& Thrift, C. (2010). Using Emergy to Value Ecosystem Goods and Services. International Institute for Sustainable Development. Winnipeg, Manitoba Canada.

Qing, H., Zheng, X. \& Hu, D. (2015). Analysis of Land-Use Emergy Indicators Based on Urban Metabolism: A Case Study for Beijing. Journal Sustainability.

Yang, H., Chen, L., Yan, Z. \& Wang, H. (2011). Emergy Analysis of cassava-based fuel ethanol in China. Biomass and Bioenergy, Vol. 35 No. 1, pp. 581589, 2011. View at publisher. View at google scholar. View at scopus.

Zhang, X., Deng, S., Wu, J. \& Jiang, W. (2010). A Sustainability Analysis of a Municipal Sewage Treatment Ecosystem Based on Emergy. Elsevier. Ecological Engineering. 36: 685-696.

Zhang, Y., Yang,Z.F., Lie, G.Y. \& Yu, X.Y. (2011). Emergy Evaluation of The Impact of Waste Exchanges on The Susatinability of Industrial System. Elsevier. Ecological. 37:206-216. 